




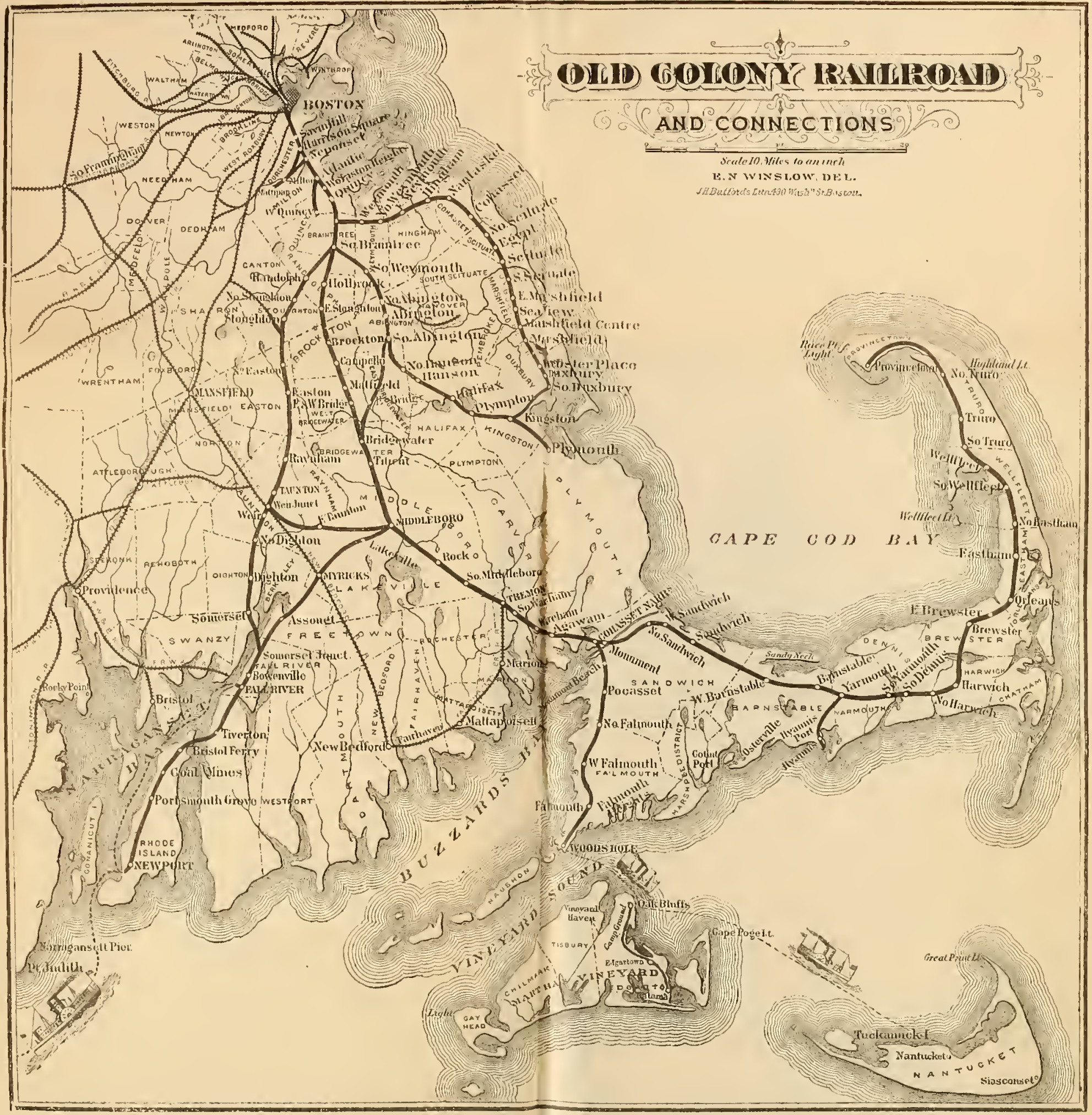



T HE

\section{Old Colony Railroad:}

ats Connections,

\section{POPULAR RESORTS,}

FASHIONABLE WATERING-PLACES.

BY BURLEIGH.

iv

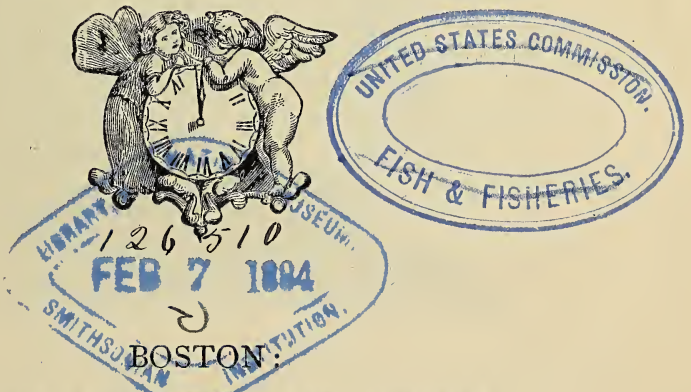

PRESS OF RAND, AVERY, AND COMPANY. I 875 . 


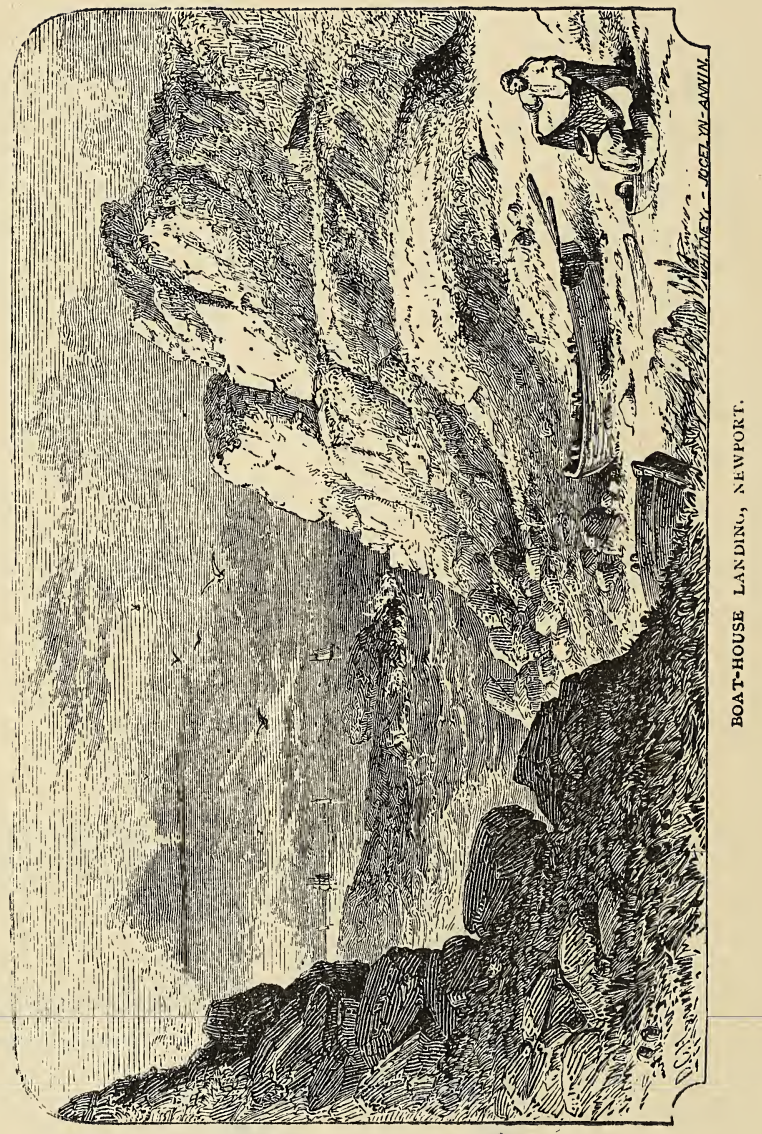




\section{THE OLD COLONY RAILROAD :}

ITS.

CONNECTIONS, POPULAR RESORTS, AND WATERING PLACES.

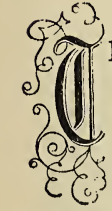

HE Old Colony Railroad, opened in 1845 from Boston to Plymouth, Mass. (37 $\frac{1}{2}$ miles), and from Fall River, Mass., to Myricks, Mass. (I2 miles), now comprises 300 miles of line, extending from Boston, the metropolis of New England, to Newport, R.I., and to all the principal cities, towns, and villages of South-eastern Massachusetts ; and, by its connecting lines of steamboats, forming the most desirable and popular route between New York and Boston, and the famous summer resorts of the beautiful islands of Nantucket and Martha's Vineyard.

A glance at the map in front shows the two lines between Boston and Newport (via Randolph, Stoughton, Easton, Taunton, Dighton, and Somerset; and via Brockton. Bridgewater, and Middleboro', converging in one line at Fall River); the line to Provincetown (the end of Cape Cod); the line to Woods Hole (the mainland terminus of the Vineyard and Nantucket steamers); the line to "Plymouth Rock," passing through the Abingtons, Plympton, and Kingston ; the Sea-Shore Line, through Quincy, Braintree, Weymouth, Hingham, Nantasket, Cohasset, the Scituates, Marshfield (the home of Webster), and South Duxbury (the American station of the "French Cable") to, and intersecting, the Plymouth line at Kingston; and the suburban "Shawmut," "Milton," and "Granite" Branches.

\section{Crye 梁oston Terminal Stations.}

The terminal stations at Boston are complete in all their parts. Their ample proportions are demanded by the heavy business of the road. The rush of passengers, coming and going, is immense. The freight, gathered from all parts of the Continent, requires acres 
of huildings. The system is complete, precluding jar and confusion in the complicated arrangements.

A pleasant feature at the Passenger Station, daily witnessed during the summer months, is the presence of the numerous picnic

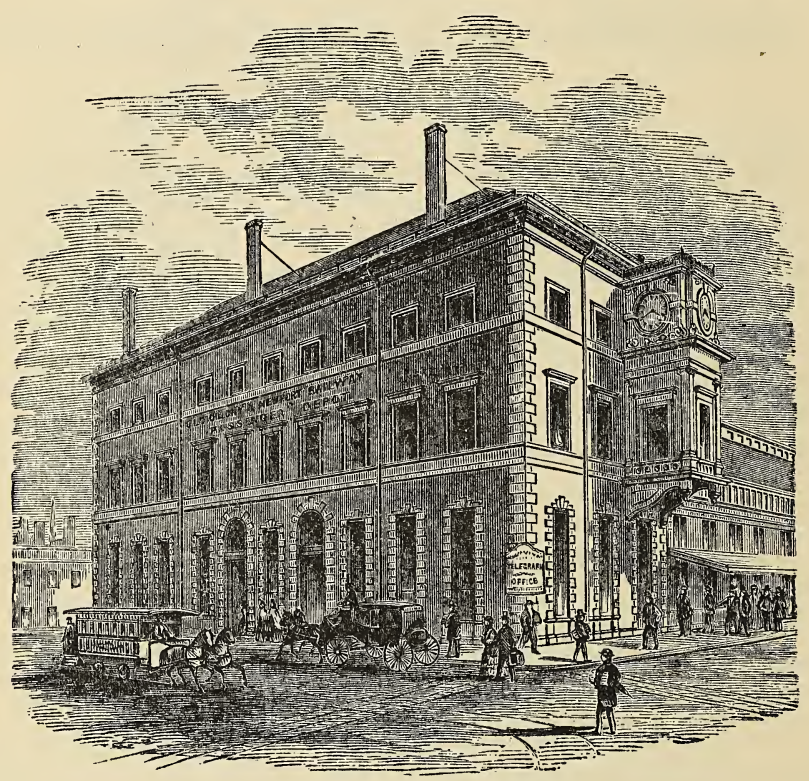

BÓSTON PASSENGER STATION.

parties bound for an excursion to the beautiful "SILver LAKE GROVE" or to the sea-shore, for a day's recreation.

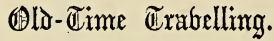

Thirty years ago, a man residing in Vermont had business in New York. Like a good husband, before he set out he made his will. Like a good Christian, he had prayers offered in the church that he might be protected on his perilous journey, and be returned in safety to his anxious family. Travellers now go around the globe 
without as much preparation, while the journey from Vermont to New York City is but the matter of a few hours.

\section{The Old Colong Commettions.}

So well adjusted and harmonized is this road, by its trunk line and branches, that it places its full facilities within the reach of the prominent cities and towns of the Commonwealth, and the principal places of interest in the country, affording an avenue unsurpassed for speedy and comfortable transit.

\section{(Ol) dfognism.}

The advance of civilization and general intelligence is determined by the modes of travel. The lumbering ox-cart of Syria indicates the degradation of the people. The queen's state coach, drawn by sixteen horses, has timber enough in it to build a modern palace car: the queen, like a sensible woman as she is, will not ride in the great lumbering thing. The sixteen horses were not for show originally, but for necessity. In the time of Charles II., the streets of London were atrocious. They were full of holes and quagmires ; and, with a great team attached, pioneers with rails and levers accompanied the coach to pry it out of the mire. The Thames was used as a highway, the streets were so terrible. The early attempts to improve the highways of London were met by a sturdy opposition: so was the attempt to light the streets. The people said their fathers and forefathers fell and broke their necks, and they would not have their own privileges curtailed.

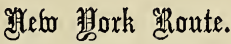

Within the last few years, great improvements have been made in the construction of steamboats and railway cars, adding largely to the comfort and convenience of travel.

In the first rank of these improvements stands the FALL RIVER LINE, whose magnificent palace steamships, "Bristol" and "Providence," plying between New York and Boston, via Newport and Fall River, have no superiors in the world. 
These superb steamers cost a million and a quarter each. The state-rooms are large and sumptuous; the grand saloons are unsurpassed. The furniture and fitting-up are not excelled by any hotel in the land. Order, system, and the most elegant accommodations greet the traveller. The ample tables, spread in European style, enable travellers to consult their comfort when they dine. All the luxuries of the season are secured. Bands of music add to the exhilarations and attractions of the passage. The officers selected are among the ablest that navigate the Sound.

This route, with its short line of road, elegant trains (equipped with the Westinghouse Air Brake and Miller Platform), and rapid transit, presents pre-eminent advantages over all others. Travellers enjoy a full night's rest, and reach either city in season for the early trains. Passengers en route for Boston find no calling-up at midnight, with a hundred miles of railroad before them. The daily rush of travel, the demand for state-rooms, the grand saloons filled with the élite of society, indicate the popularity of the Fall River route.

On page 26 may be found an illustrated article, from the "New York Nuutical Gazette," giving an excellent and interesting description of the world-renowned steamships "Bristol" and "Providence," the "floating palaces of America."

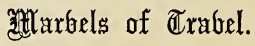

The iron pathway and the facilities of travel have made these two cities, Boston and New York, practically one. A few years ago merchants interchanged visits once in six months, and made purchases for the season: now merchants rush on to New York in the night, spend the day in business, take the palace steamer in the afternoon, dine at their leisure on the boat, have a sleep in rooms as elegant as any at a first-class hotel, and, refreshed, are ready for business next day. Said a merchant, "I received a telegram at noon that my ship, loaded with tea, was at Sandy Hook. I took the 5.30, P.M., Old Colony train for Fall River, had a good night's rest on the boat, reached New York in the morning, met my ship at the dock, sold the entire cargo, took the 3 o'clock train, and slept in my own bed in Boston the same night." 
THE OLD COLONY RAILROAD.

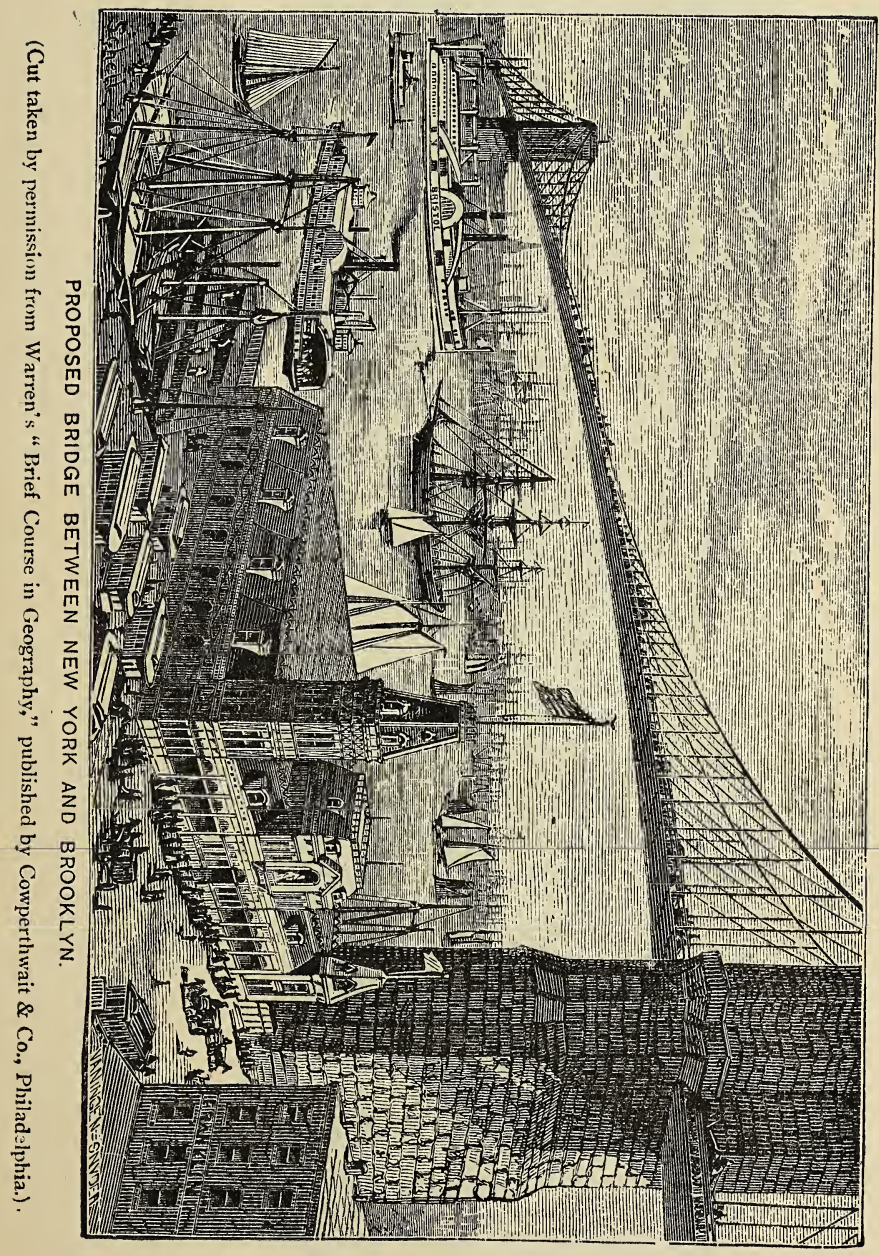



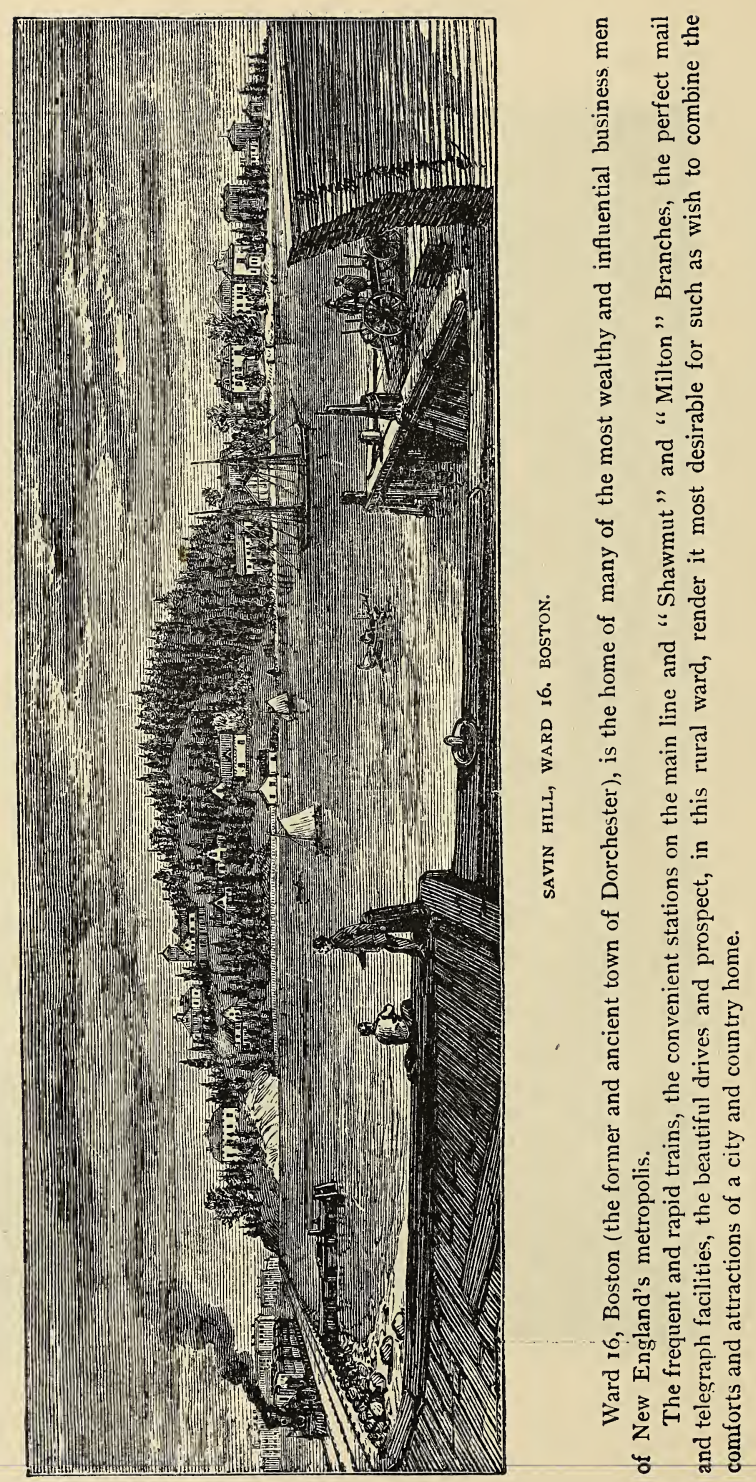


\section{first-class 解nsiness.}

In every style and department of business, there must be a foremost company. Travellers should be as wise as men are in ordinary trade. Men prefer to deal with a first-class, successful house, put up at a leading hotel, hire a first-class carriage, put their money in a sound and reliable bank. So in travelling: a finely-appointed road, run with enterprise and liberality; managed with intelligence and care ; with cars combining all modern comforts ; running through a country unsurpassed for its ocean-views, its inland beauty, with a pathway around which cluster the most interesting historic memories ; touching the great watering-places of the country, and by its connections reaching the snows of the North, the southern savannas, and the illimitable Pacific,-offers to the travelling public superior attractions.

\section{(Enterprise of the 象oad.}

It is conceded that the Old Colony Road is one of the best appointed in the country. It stretches out its iron arms in every direction. It connects Boston with the great watering-places of the east, and, by its connections, also with Saratoga and Niagara; the seashore connected with the White Mountains, Newport with the Hoosac Tunnel, with the British Dominions on the one hand, on the other New York and the great South and West. The consolidation of lines lays the traffic and commerce of the country at the doors of the Old Colony. Its rails extend over a third of the State of Massachusetts, grouping together Boston, Newport, Plymouth, New Bedford, Martha's Vineyard, Nantucket, Cape Cod, and New York.

\section{The ifinsiness Halue of a çoad.}

The map shows the marvellous connections with the Old Colony. The perfect system which marks the completeness of this railway is not the work of an hour: it demanded years of toil, and an outlay gigantic in its character. The growth of Boston shows the business value of such a roadway. Hundreds of towns and villages have been called into existence. Countless manufactories 
have sprung up in the valleys. Sterile farms, that scarcely afforcied sustenance for man or beast, teem with a busy population, making the poor farmer a rich man. Men who dwelt in the lanes and narrow tenements of the city now breathe the healthy air of the country, and get to business or labor cheaply and on time. A railroad in a town is like a mine of gold; and land, produce, and labor feel its magic power. The snorting of the iron horse indicates prosperity.

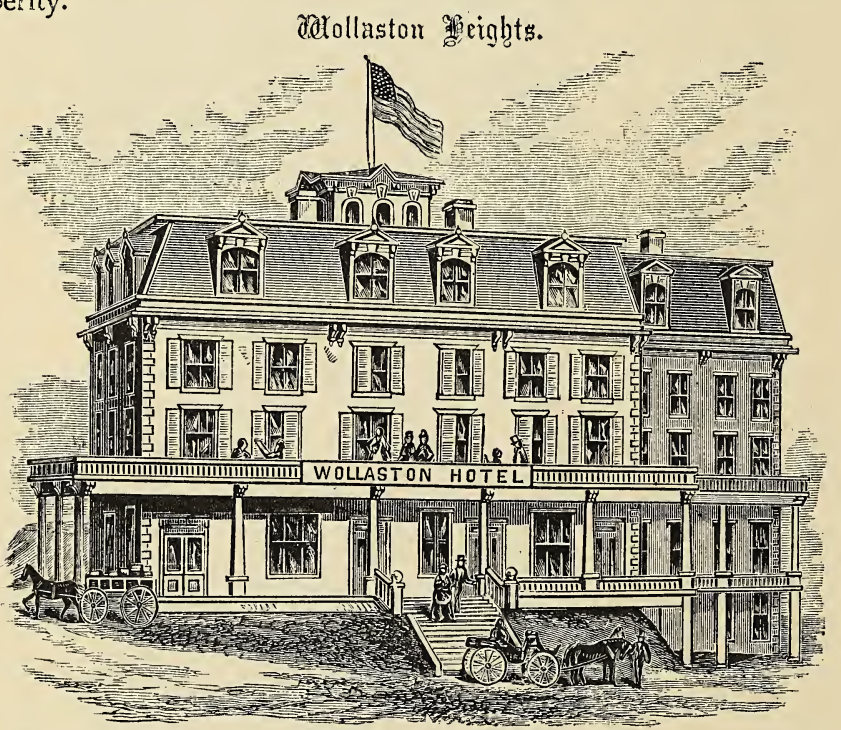

This is one of the most beautiful of the su'jurban towns sur. rounding the "Hub." Charmingly located on the south shore of Massachusetts Bay, only six miles from the city, overlooking Boston's magnificent harbor, with its scores of islands, - not a vessel or steamer can pass in or out without being seen, - in full view of the glittering dome of the State House, it is rapidly becoming a select, favorite spot for homes.

This place has grown up as if by magic. Ground was broken for the first house in the spring of 1870. Now there is a village of nearly one thousand inhabitants, with all the paraphernalia of a. 
first-class town, - schools, churches, stores, post-office, \&c. ; and, last but not least, thirty trains daily to and from Boston.

For beauty of location, for charming scenery of land and sea, of city and country, of village and hamlet, for picturesque walks and drives, for magnificent views, for facilities for sea bathing and boating, healthy climate and pure water, in fact, for every thing which serves to make home desirable and attractive, Wollaston Heights is unsurpassed.

The temperance advocate will find here his ideal, as the sale of intoxicating liquors is strictly prohibited by a law which executes itself ; the deeds conveying the property containing a clause which forever proscribes this and all other kindred nuisances.

The Wollaston Hotel is located here, near to the station, - a first-class house, and is well patronized by boarders from the city. It is really more convenient of access than the South End of Boston. The trains are so frequent, that one can go to or from the city at almost any hour he may choose, from early morning to late at night.

\section{The Totor of (2) ining.}

Without reference to its great Eastern, Southern, and Western connections, the Old Colony runs through a country full of the picturesque and historic. Among these, prominently stands the old town of Quincy. Prominent among its attractions is the mansion of John Adams, the second president of the United States, and John Quincy, his great son. The rude and humble dwelling, with its roof sweeping down to the ground, where John Quincy was born, is worth looking at.

The road towards Boston still exists, over which John Quincy rode post to old Boston Town, carrying the mail. The pasture can be seen where the lad of twelve, one frosty morning at five o'clock, crying with the cold, followed his father to take boat for the ship and sail for France.

The town is full of Revolutionary memories. It is also interesting from the fact that in it was laid the first railroad for traffic ever built in the country, - a tram-road to connect the immense granite ledges with tide-water, now operated by steam-power as the "Granite Branch" of the Old Colony. 


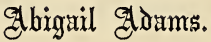

The Adams mansion, at Quincy, will always be identified with the heroic career of the wife of the second president. The daughter of a minister, trained to the intelligence and economy of the parsonage, she was well fitted for the position to which she was called. She was a model woman of the Revolution.

The absence of her husband, on public affairs, threw the management of the farm, and the support of the family, upon herself. She knew want and terror.

Eight miles away, in the town of Boston, the British held possession : their guns could be distinctly heard in Quincy. The foraging expeditions kept the country in a state of alarm. How much Mrs. Adams suffered, her published letters show. But she never flinched, nor deserted her post. She heard the shouts of triumph when Boston was delivered. She lived to have the high honor of being the first lady who graced the White House.

\section{The (quincy Afedoges.}

From these granite ledges have been taken the material for many of the public edifices throughout the country.

When, about the middle of the past century, the dilapidated condition of the King's Chapel in Boston necessitated its rebuilding, it was voted to replace the wooden structure by one of Quincy stone. During the rebuilding it was feared that the supply of granite would be unequal to the requirement; and a survey was ordered, the result of which was, that probably a sufficient quantity of stone could be obtained from the quarries to complete the chapel, and possibly enough more for another such building.

Since that time the constant labor of multitudes of workmen has made but trifling inroad upon the immense mines of granite contained in the Quincy hills.

The manner of working the quarries, the "incline" down which are transported the huge masses, the wild scenery, are of no little interest, and well repay a visit to the region. 


\section{(0) ID glinmouth.}

This ancient town should be visited by every American. A ride of thirty-seven miles, in the superb coaches of the Old Colony,

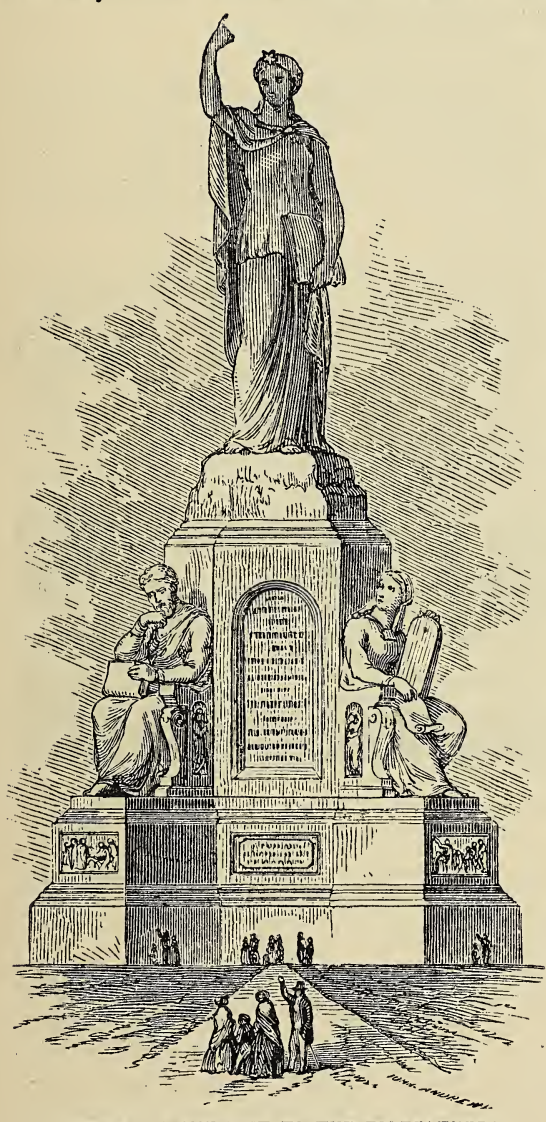

NATIONAL MONUMENT TO THE FOREFATHERS.

brings the traveller to "Plymouth Rock." The town is crowded with paintings, curiosities, furniture, and memorials of the Pilgrims.

Every spot is interesting, - the famous Rock itself ; the garniture and curiosities from "The Mayflower; " the site of the first meeting-house, where worshippers sat at the ends of the pews, with guns in their hands, ready to repel the invasions of the savages; Burial Hill, where the graves were smoothed down, that the Indians might not know how many of the Colonists had died; and Clark's Island, where the exiles "rested, according to the commandment," on Sunday, Dec. 10, 1620.

Plymouth is famous as a watering-place. Its climate is salubrious; its bay unsurpassed for healthy sports ; its hotels ample and well kept, challenging the attention of all who are 
seeking healthful relaxation, with the pastimes and sea-breezes that bear healing and strength on their wings.

\section{The City of ateborport.}

A ride of less than three hours from Boston brings the traveller to Newport. This is without a rival, the fashionable watering-place of America. Its magnificent sea-view, its unsurpassed beach, its driveways and boulevards, its private cottages and magnificent

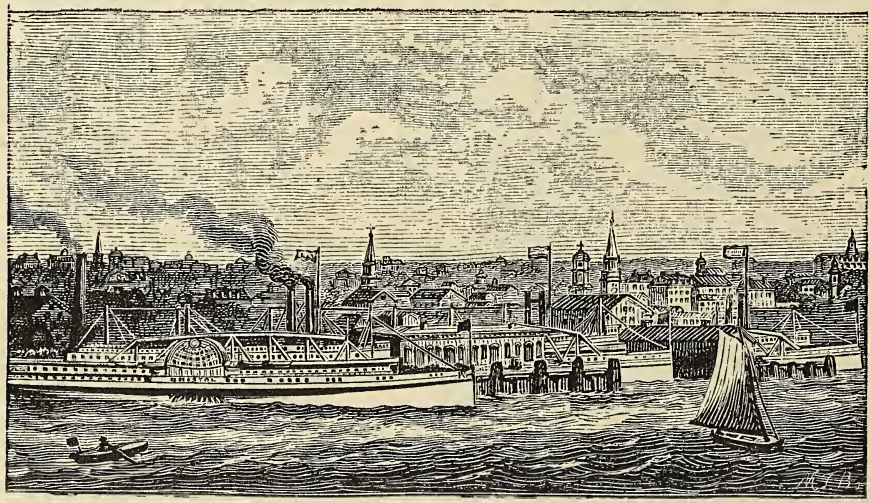

NEWPORT, - FROM THE BAX.

public and private dwellings, cannot be equalled on the continent. Its hotels have long been famous as the most celebrated in the country.

Newport offers unrivalled facilities to those who enjoy the whirl of fashionable life at a watering-place: at the same time it offers repose and quiet for those who seek retirement. The curious traveller will seek out the house of Dr. Channing, and listen to the sweet strains of the organ in Trinity Church, given by the renowned Bishop Berkeley in I 729. The statue of Com. Perry, the Stone Mill a thousand years old, Fort Adams, all merit a visit; and all will 
admire the beauty and taste of the private dwellings of the eminent men of the land.

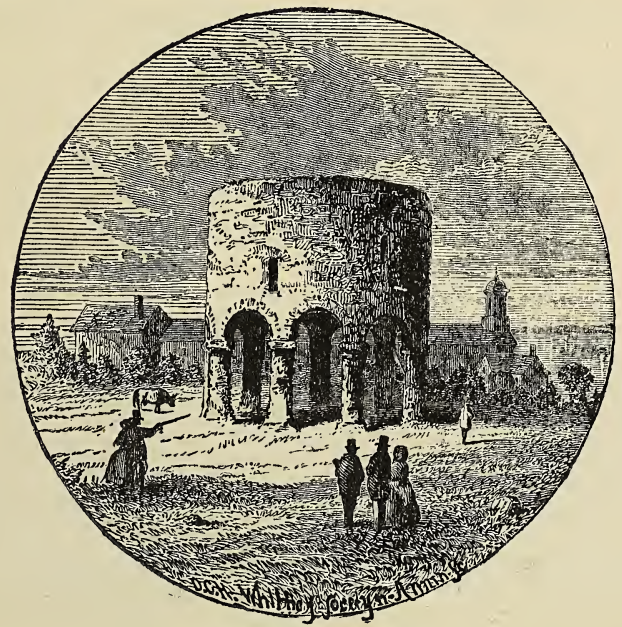

OLD STONE MILL.

A Curious Custom.

The Second Baptist Church is worth looking at. For over a hundred years, no music or singing was allowed in the church. It was finally introduced sparingly, amid great excitement and much opposition. Many were conscientiously opposed to singing in public worship, mainly because their fathers did not sing.

When the hymn was given out, a company of men and women arose, went outside of the church, and stocd on the bleak hill, often in a snow-storm, often with the thermometer at zero, and remained until the hymn was finished, when the conscientious party re-entered the house to hear the sermon.

In consideration of the scruples of weak brethren, the church passed a resolution that those who could not sit in church and hear a hymn sung should be pərmitted to withdraw, and not be dealt with as contumacious persons. 


\section{đlye citg by the Sex.}

This is the poetic name given to Oak Bluffs, on Martha's Vineyard, with its hundreds of cottage-houses by the sea. The sail from Woods Hole in the elegant steamers that ply between that place and the Vineyard and Nantucket, is simply magnificent. Buzzard's Bay is studded with beauty, and places of rare and historic interest. The entire fleet plying between New York and the East passes in sight of nearly all the prominent hotels, bringing into view often a thousand sail.

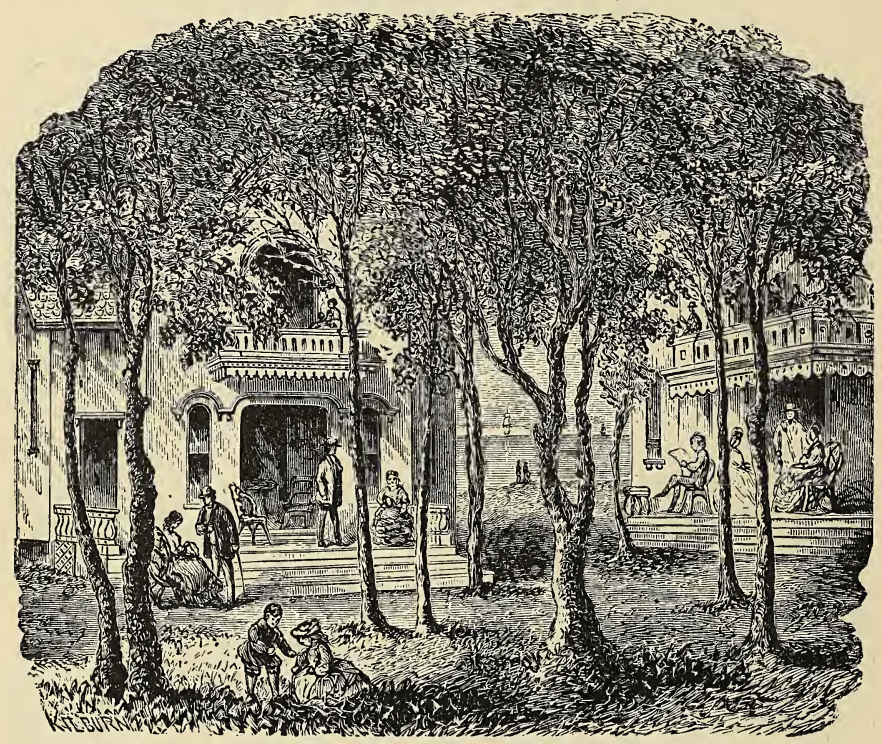

OUT-DOOR LIFE AT THE VINEYARD.

Penikese Island, immortalized by Agassiz, lies in full view.

At the westerly end of the Vineyard is " Gay Head," pronounced by Webster one of the greatest natural curiosities. More curious than all is the new city of Martha's Vineyard, Oak Bluffs.

Thirty years ago a number of Methodists held a meeting under a tent. A few years ago a steamer of moderate capacity carried 
all who wished to visit the Vineyard. Oak Bluffs is now a city: it has concrete drives, with an ocean view, and fine roads eight miles long. The city has gas street-lamps, horse-railroads, a trottingcourse, and a:l modern improvements.

It is a Liliputian city. Its houses are cottages, a thousand in number; some of them very costly, and owned by the most noted men in the country. The city of the Vineyard has two sides. The Camp-Meeting Association, with its marvellous tent holding five thousand, with its cottages, is as distinct from the revellers and pleasure-seekers, as if it were a thousand miles away. Outside of the "Circle" dwell the people who come for recreation and pleasure.

The Sea View House, whose foundations are bathed by the waters of the bay, is one of the most complete and superb watering-

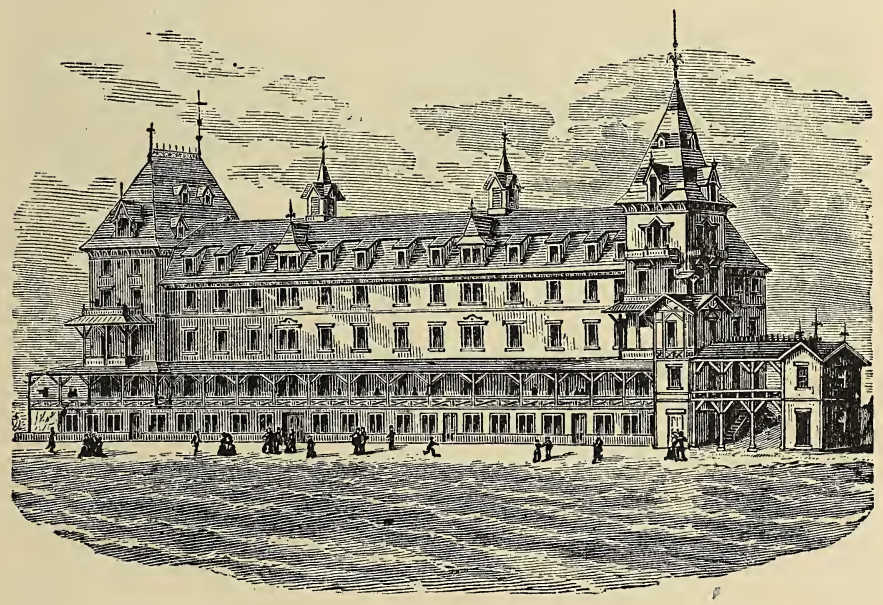

SEA VIEW HOUSE.

place hotels in the world. It has a plank walk for pedestrians, a mile long; a seashore for bathers, and the pure ocean, without surf or peril, with nothing between the bathers and Ireland. There is a fine beach-road to Edgartown, and a narrow-gauge steam-railroad to Katama, which latter place, with its magnificent hotel and royal surf-bathing, attracts many visitors. As many as fifteen thousand 
persons have been on the island as visitors at one time. It is the most unique and attractive watering-place in the world. Boardingplaces are abundant; and hotels are numbered by scores.

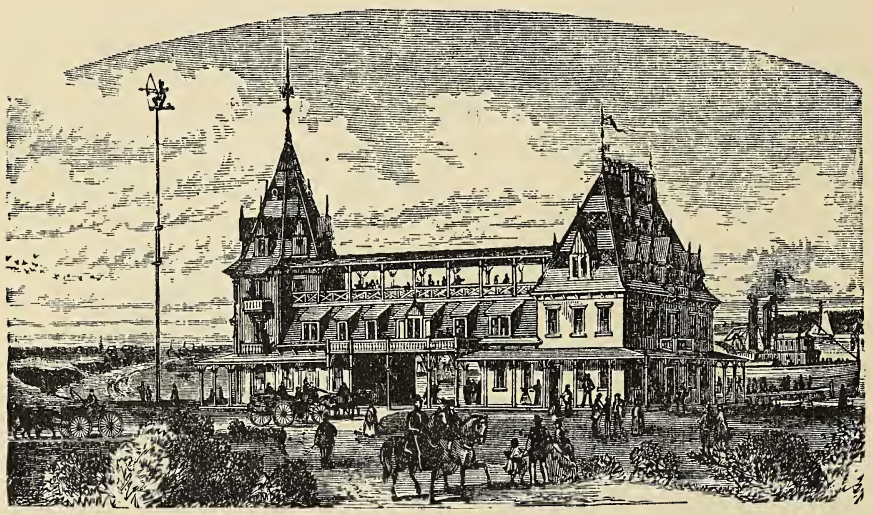

MATTAKESET LODGE, KATAMA, MARTHA'S VINEYARD.

\section{Societij at the Hinemard.}

The two phases of society, the devout and the fashionable, as unlike as can be, harmonize marvellously. The portion devoted to religious families is known as the "Circle." It is connected with the outside world by a street-railroad. It is beyond the reach of the cheer of the trotting-course, the whirl of the dancers, the gay music of the band, and the loiterers who watch the bathers and sailors and promenaders in their merry groups. Outside of the "Circle," society is as elegant as any at Saratoga, Newport, or Niagara. All the sports and pastimes of a fashionable wateringplace are enjoyed. The cottages are tasteful, some of them very elegant; and at night, when they are illuminated, the whole city has the appearance of a fairy village.

Oak Bluffs, the Vineyard City, is unique and elegant, and worth crossing continents to see. 


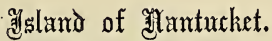

Thirty miles out at sea is a tufted sandbank fifteen miles long: on it is the quaintest and most old-fashioned town in the Commonwealth. The zeal and energy of its hardy seamen, who pursued the whale in its arctic home, made Nantucket in earlier times familiar to the British Parliament. 'Nantucket is now coming to the front as a watering-place. Its fine air, the facilities for the rugged sports of the seaside which it offers, its bracing and genial air, the many attractions that surround it, the absence of fogs, and the home attractions presented, the easy sail of two hours, - all commend Nantucket to parties in search of out-door excitement and healthy recreation.

The town is specially attractive to invalids who seek quiet and repose, with the invigorating sea-breeze and the attractive sail. Not the least among the attractions of the place are the facilities of arrival and departure. Visitors can take their breakfast at the White Mountains, and sleep in Nantucket: men of business can reach New York or the White Mountains as easily as from Boston. The connections are swift and sure for travel, East, West, North, or South. The town is full of quaint customs. Lectures, meetings, and arrivals are announced by the bellman. The coaches are carts, in which passengers stand. Young ladies invite their friends to a ride, back up a one-horse cart to the door, take in their freight by means of a chair, and drive off as a fashionable lady in the city would turn her phæton into the park.

Nantucket is full of attractions. Its hotels and boarding-houses are ample: its athenæum, library, marine curiosities, its ancient houses of 1686 , and the residence of the last of the Indians, are full of historic interest.

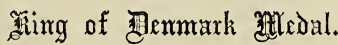

Nantucket has long been celebrated for the intelligence and talent of its women. The training of the household, and the duties of social life, devolve mainly upon the mothers and sisters. The men pursuing the arctic whale, on their long voyages from home, 
THE OLD COLONY RAILROAD.

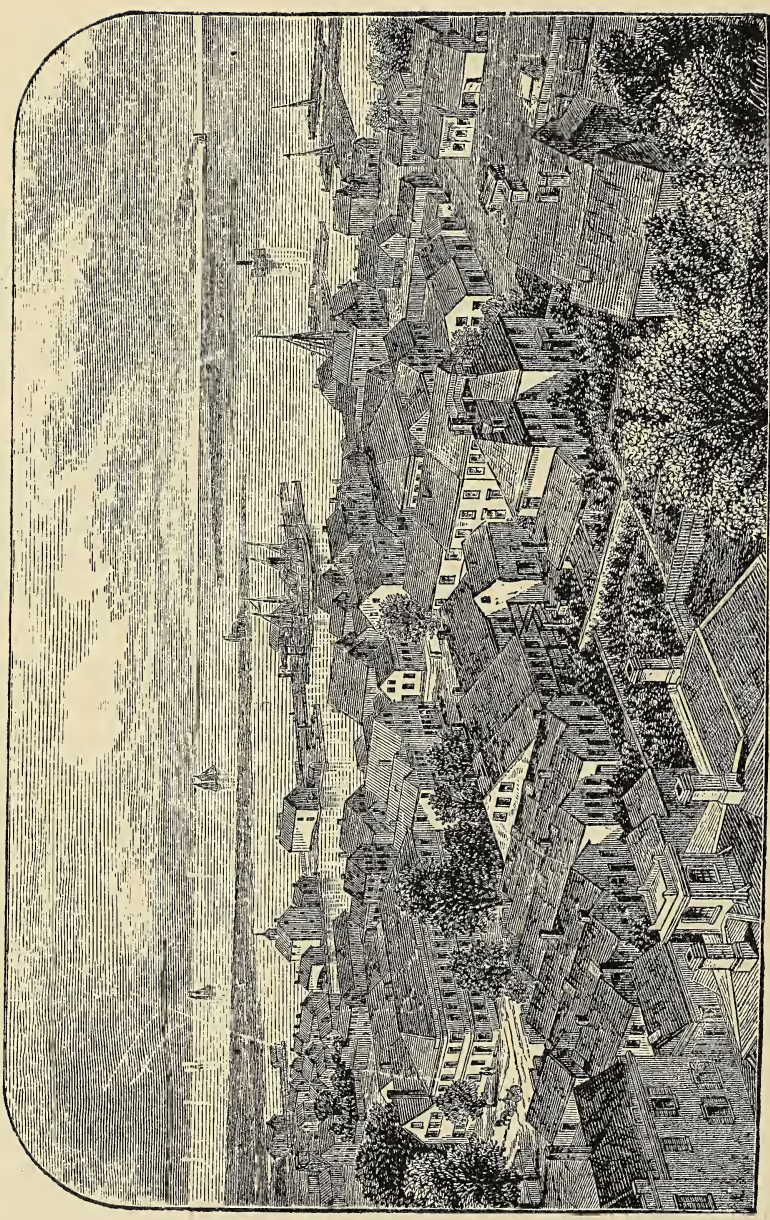

 
the correspondence with their friends on the sea gave the women of Nantucket a superior intellectual advantage.

The King of Denmark offered a gold medal to any one who discovered a telescopic comet. A fair maiden of Nantucket, then all unknown to fame, had blended the study of astronomy with domestic duties. She had the care of her aged parents: she was an especial favorite with the boys and girls of the island, mending their tops, whips, and dolls, tying up bruised and damaged fingers, and keeping a perfect arsenal to assuage the woes and sorrows of childhood. She entered the race for the medal; and, though kings and nobles were her competitors, she bore away the prize.

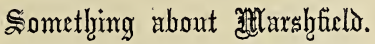

Marshfield will always be attractive, as it holds the farm and mansion of Webster by the sea that he loved so well.

Besides the mansion and magnificent grounds, apart from the dwelling, stands the little white office where he did his morning's work, and allowed no one to disturb him. A few rods away, in the rear of the mansion, runs a little brook that has an historic interest.

Webster the farmer did not look much like Webster the Secretary of State.

He was trimming trees one morning by the rivulet, with his slouched hat and heavy boots. An aide from the Governor of New York had a message to the Secretary of State. He attempted to run across lots to Webster's farm. He hailed the Marshfield farmer: "Old man, where is Mr. Webster's place?" - "This is it." - Is he at home?" - "He is on the farm." — "How can I get across the brook?" - "Some wade, and some jump." - "I'll give you a shilling to carry me across the brook." With great deliberation the great statesman forded the brook, took the young sprig on his back, landed him on the right side of the water, pocketed the shilling, pointed the way to the mansion, and afterward met the blushing messenger in his library. 
THE OLD COLONY RAILROAD.

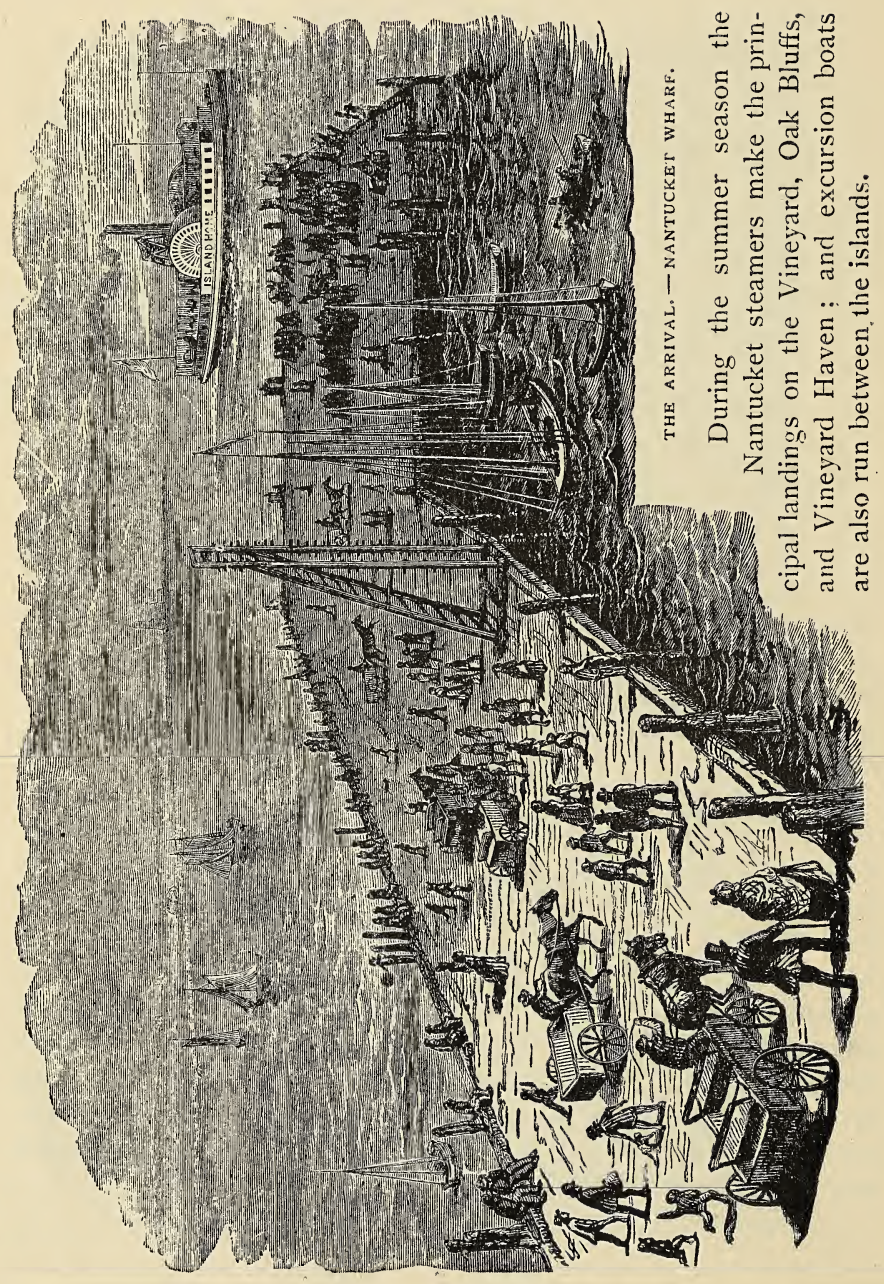




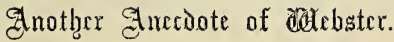

I was once in company with Mr. Webster. Nantucket was spoken of. I said to Mr. Webster, "Is it true that the Friends of Nantucket farmed you out as a lawyer?"

"Well," said Daniel, laughing, "they are a sharp people at Nantucket; and I will tell you how it happened. The courts held their term on the island periodically. There was not much litigation; but the suits were heavy, relating to ships, whale-fishing, and oil. The judges and lawyers usually went over from the continent, and spent a week or ten days, and finished the business of the term.

"One day one of the Friends of the island called at my office in Boston, and said, 'Friend Daniel, what will thee ask to come down to Nantucket next week, and plead a cause for me before the judges?' - 'I will go for a thousand dollars.' - 'That is too much, Friend Daniel.' - 'But I will have to go down Saturday, and perhaps remain the whole week following. I would as soon argue the whole docket.' - Well, Friend Daniel, if thee will argue such cases as I will present to thee before my case is called, I will give thee a thousand dollars ;' and so the bargain was struck.

"My client went to N.ntucket, and found his cause at the foot of the docket. He went from man to man, and store to store, who had any cause on the docket, and said, "What will thee give me, if I'll get the great Daniel Webster to plead thy cause?' He took retainers from a dozen men. Some gave him a hundred dollars, and some five hundred dollars. He had grace enough to give me the thousand dollars as agreed, and paid my expenses into the bargain. I argued the docket right through, for plaintiff or defendant, till I reached my client's case. He struck the balance, and admitted, as the steamer left the wharf, that he had got his own case argued, and pocketed fifteen hundred dollars besides."

(1) ine of the (Ends of Eartly.

A hundred and twenty miles from the Boston station, in the arm of Cape Cod, lies the town of Provincetown. For years it 
was isolated, and still retains the quaint and ancient customs of the olden time.

The Old Colony road brings the town within a business distance of all the great centres of trade. The town has a wild and weird look, high hills of sand, bluffs, and promontories attesting the power of the ocean. The attractions of Provincetown as a watering-place are recognized. The climate is delicious, free from fogs, with a sweep from the ocean unsurpassed for its mildness and purity. The ride from Boston to Provincetown is a panorama of beauty.

Once in the town, one is as quiet and isolated as if a thousand miles away from the metropolis.

In the summer, the town is crowded with visitors. The hotels are numerous, and private boarding comfortable and reasonable.

\section{Peambing of the gillgrims.}

Provincetown shares with Plymouth the honor of the debarkation of the Pilgrims.

Forty-one days before the Pilgrim Fathers struck Plymouth Rock, "The Mayflower" cast anchor in the magnificent bay of Provincetown. Here the great charter was signed, which became the corner-stone of our republic, affirming that majcrities must govern.

From Provincetown, Marshfield, Duxbury, and Clark's Island were visited.

The landing at Provincetown, "Nov. I I, I620," is commemorated by a marble tablet in the town hall, which stands on the prominent promontory of the cape.

\section{attiscrllancous.}

The visitor to Martha's Vineyard will not fail to make a trip to Gay Head, and look on the wonders of its variegated soil. Katama Bay, with its fine hotel and driveways, with its magnificent surf-bathing, will command attention. Buzzard's Bay, with its . headlands and outlying islands, have especial attractions. The 
Elizabeth Islands - the group known as Cuttyhunk, Penikese, Neshawana, Peskanese, Naushon (the summer residence of John M. Forbes, Esq.), possess peculiar attractions. The wateringplaces on and around the Vineyard are full of attractions.

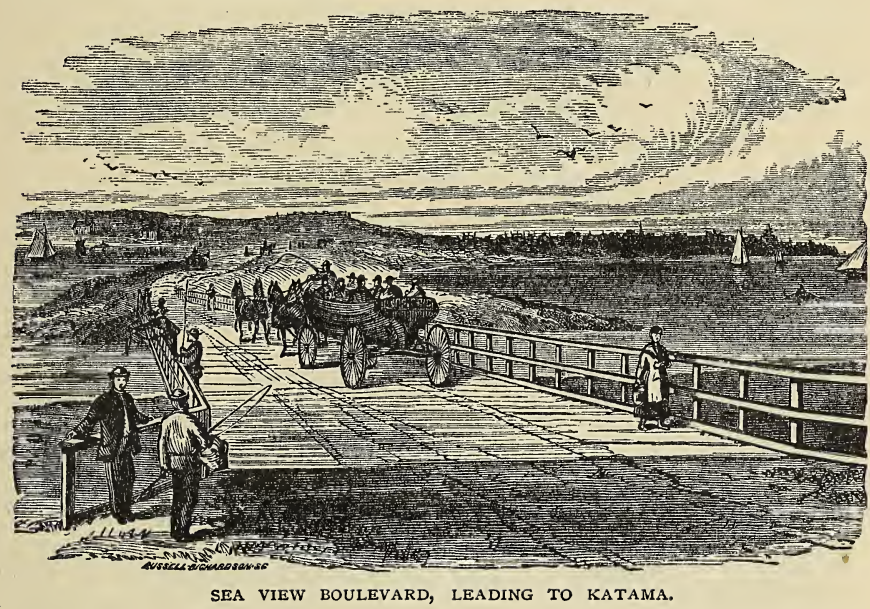

In the hottest summer day a cool breeze is enjoyed, while there is an abundance of fish and game of every description, with bathing, yachting, elegant company, and all the luxuries of the season.

In conclusion, the facilities of travel, easiness of access, and constant communication with all parts of the country, the mail and telegraph facilities, place the Old Colony and its connections in the fore-front of attractive railroad routes in the country.

Travellers are referred to the charming volume entitled, "Nooks and Corners of the New England Coast," by Samuel Adams Drake (just published by Harper \& Brothers), for a more extended description of the principal resorts here mentioned. 


\title{
FALL RIVER LINE
}

\section{BETWEEN NEW YORK AND BOSTON.}

\author{
(OLD COLONY RAILROAD AND STEAMBOAT COMPANIES.)
}

AMERICA'S FLOATING PALACES.

\section{Illiustrated Description of the Steamers "Bristol" and "Providence."}

\section{[From the Nere York Nautical Gazette.]}

THE modern traveller must journey with speed. His surroundings, while on board of any class of vessel, must be luxurious; and, where these requisites are to be found, he goes, and scarce demurs at the price. Nowadays the public must work by day, and travel by night, so that no time shall be lost. And the route is not so much of a question as the type of vessel which is to carry them to their destination. Our people are peculiar; and one of the great secrets of success in managing a steam vessel line is to know how to please them First, the size and grandeur of the boats must be impressive; secondly, all their appointments must be complete in every respect; and, thirdly, the management must be comme il faut. There is no steam line engaged in inland traffic which can so justly boast of having as large and fine a fleet of vessels as the Old Colony Steamboat Company. Two of its steamers are the largest in the world; and it is not exaggeration to say that they are the finest on the globe, without any exception. It is our purpose, at the present writing, to describe and illustrate a type of vessel peculiarly American, and which has never been excelled in any part of the globe.

"The Bristol" was built by W. H. Webb of this city, whose handiwork floats on every ocean to-day, and whrse beautiful specimens of naval architecture have everywhere been admired for their grace and symmetry. The reader can get but a faint idea of the magnificent proportions of "The Bristol" from the descriptive text now presented to his eyes; yet the artist has done his part exceedingly well. Sin is 373 feet in length, 83 feet beam over all, and 16 feet depth of hold, the hull 
proper measuring 3,000 tons. The massive machinery was designed by Erastus W. Smith, consulting engineer, and built by John Roach \& Son of this city. The engine is of the vertical beam type, with one I ro-inch cylinder and 12 feet stroke of piston, developing a power equal to 2,800 horses. Steam is furnished to this giant engine by three low-pressure boilers, each of which are 35 feet long, and I 49 inches diameter of shell. They are made of the very best boiler plate-iron, $3 / 8$ inches thick : each has 10 main flues, and 136 return flues 5 inches in diameter; each one tested to allow the boat to carry 34 pounds steam, the usual working pressure being 24 pounds to the square inch. She has two feed-pumps $8 \frac{1}{1}$ inches in diameter and 69 inch stroke. Scattered through the saloons.

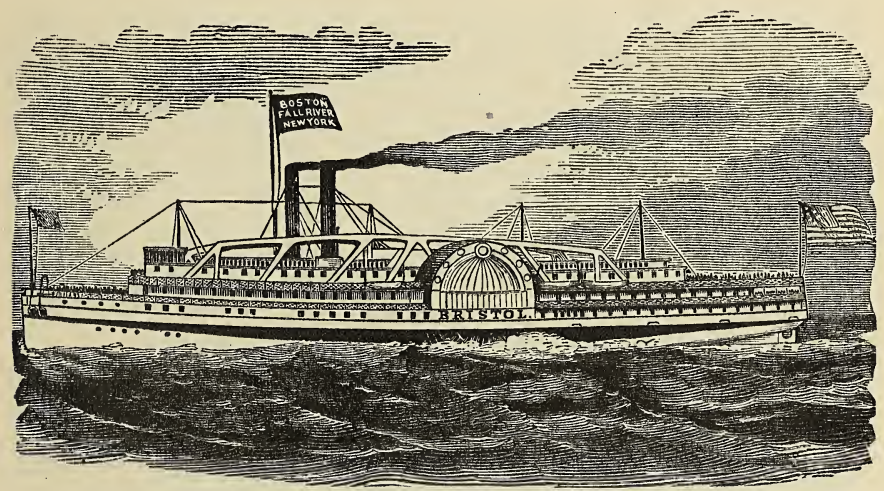

THE OI,D COLONY STEAMBOAT CO'S STEAMER "BRISTOL."

in sundry places, are fire-extinguishers ; 3 large fire-pumps are ready at all times, with hose attached, and having 15 connections ; fire-buckets are distributed in convenient places; large water-tanks are always filled and ready for use ; and axes are in their proper places. "The Bristol" has I3 life-boats, all of metal, two large life-rafts, and cork mattresses : 700 cork life-belts are on board, and one is placed in each berth.

To man one of these immense floating palaces requires one hundred and thirty persons, divided as follows : captain, officers, and crew, 40; engineers' department, 24 ; steward's department, 61 ; watchmen and lookouts, 5. Oftentimes this total number is largely increased.

Before we go into the descriptive details, let us say, that, in every part of the vessel, the best of materials have been used, and ail that art of 
man could do to make these vessels perfection in strength, beauty, and safety, has been done.

As we enter the boat, and pass the portals of the gangway door, we are ushered into the Social Hall, the flooring of which is of black walnut and yellow pine, laid in narrow strips. The ceiling and panelling is in the highest style of the decorator's art, who has combined the daintiest of colors to produce an effect worthy of the old masters. Heavy rosewood doors are on either hand, and rich gas-jets light it up like a fairy grotto. On one side is the clerk's office, and, on the opposite side, the tonsorial artist's rooms, with toilet arrangements complete in every particular.

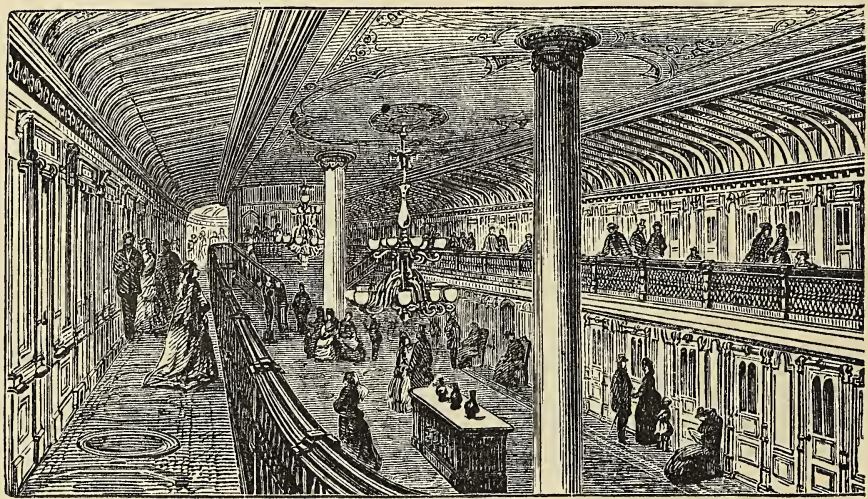

INTERIOR VIEW OF GRAND SALOON.

After glancing around for a few minutes, one seems at a loss which way to go ; for the beauties of the other parts of the vessel are now revealed, as either the doors leading to the ladies' saloon, or those leading to the grand saloon, are opened by those passing to and fro. We shall be obliged to lead the way to save time, and first take the visitor into the ladies' saloon. Here richness abounds on every hand. Velvet carpets, rich and heavy furniture upholstered in velvet, and embroidered in chaste patterns, costly chandeliers, and all the appointments of ease, luxury, and refinement, are on every hand. You peep into the state-rooms on either side of the saloon, and snowy linen lace curtains and all modern conveniences meet your gaze. Beneath this, again, is a less pretentious saloon, but just as neat and tidy as the other. 
Leaving this attractive spot, let us ascend the grand staircase, which leads to the grandest steamer saloon in the worlc. This saloon is 275 feet in length, 28 feet wide, $2 \mathrm{I}$ feet high. The staircase itself is worthy of a passing look : it is of mahogany, inlaid with satin and other rich woods; and in each of the newel posts is a petite chandelier, fit for the boudoir of a nymph. We are now in the main saloon, nearly 300 feet in length. Those who have never been on board of one of these palaces cannot imagine the surprise that awaits them. Elegance, magnitude, and superb fittings greet the eyes, whichever way they turn; and for a time you are unconsciously lost in wonder. From the half domed ceiling drop costly chandeliers, in the sunbeams darting forth the bright rays of the trembling prism, or by gaslight sparkling with all the brilliancy of a tiara of diamonds. Soft, velvety carpets hush your tread; luxuriant velvet plush-covered lounges, chairs, divans, and ottomans invite you to rest. Their frames are of heavy carved black walnut, relieved with clelicate gold stripes. Rich tints combine to make the tout ensemble all that the eye could wish ; and heavy mirrors reflect back the gorgeousness of the scene, which, for a time, chains you to the almost enchanted spot. Cleopatra's yacht may have been more costly, with its inlaying of pure gold, pearls, and precious stones; but we doubt if it excelled " The Bristol" in all the points of beauty of finish. Our time is limited, and we must call you from this scene to others of equal interest. We have shown you the luxuries intended for the throng: let us open one of the 240 stateroom cloors. This one is a bridal-room : there are nine of them. Let us enter. It is vacant now ; but we will venture to say that it is already engaged, but the bride and groom have not yet arrived. While they tarry, let us look. Even richer carpet overlays the floor; a massive bedstead, dressing-case, wash-stand, marble-top table, and chairs are the furniture of this large room; for it is nearly as large as a bedroom in a Fifth Avenue mansion. The upholstery and fittings are magnificent. Snowy linen, downy pillows cased with the finest of coverings, rare lace curtains, and heavy mirrors, make it fit to be the bridal room of a queen. Each of these rooms is as richly decorated, but several of them are in different colors; so that no "sameness" marks these special chambers, Next we peep into the family rooms, quite as good as those set apart for the newly-wedded ones, but not quite so profusely decorated. As we turn to go forward, the attention is drawn to two fine bronze figures, which are placed on top of the newel posts at the foot of the stairs leading to the gallery. Each figure supports a brilliant chandelier, on the globes of which are painted vivid fruits and flowers. Each of these 
superb works of art cost several hundred dollars. This saloon has a gallery, which is reached by a light but costly staircase. Here are located some of the pleasantest rooms on the vessel; and they are specially desirable on moonlight nights, when the occupant can gaze from his room window over miles of blue waters, watching the passing vessels, or the glare and glimmer of the lights which mark to the mariner his lonely way over the fathomless waters.

We have strolled out on the promenade-decks, looked down on the knots of humanity which are beginning to throng the dock, and fill up the boat; and now let us look below, and into the dining-saloon. Here are over 300 berths for gentlemen, on either hand, below the main deck. but in the dining-saloon the berths are enclosed in state-rooms, and are out of sight. Meals are served on all the boats of this line $a$ la carte, "you order what you want, and pay for what you get." This diningsaloon is a feature worth noting. Separate tables to accommodate a halfdozen are provided: over each is a beautiful chandelier, which gives a fine effect to the scene. The decorations are in keeping with all the other parts of the boat. The silver is massive, the glass chaste, the china appropriate, and every thing is inviting and attractive about the place.

We have written this description in an offhand, familiar way, rather than follow dry facts ; but we must honestly say to any one who has not seen "The Bristol," it is worth many a dollar to go over her and inspect her. It is true, some idea can be obtained of her magnitude and breadth from this article; yet to appreciate these really floating palaces, you must go on board. As familiar as we are with them, we never fail to find some new attraction when looking at them.

The same grandeur of proportions as marks the sister boat are to be found on "The Providence," and there are many who travel on this line. who scarce can tell one from the other; yet there is a perceptible difference when you come to examine closely the interior decorations. In upholstering, different colors have been introduced, and blended with a richness of effect not to be found on any class of vessels in the world. Amid all this luxuriousness of outfit, cleanliness and order prevail everywhere. The massive machinery shows not a dot of rust; the more elaborated parts of the engine shine like a new silver dollar; while as much care, if not more, is bestowed upon the efficiency of this large and powerful triumph of the engineer's skill.

The "Bristol" and "Providence" originally cost \$1,250,000 each, - a handsome fortune in itself; and to keep them up to their proper stand- 
ard costs in the neighborhood of $\$ 150,000$ yearly. Both of these boats have been most thoroughly overhauled in boilers, machinery, hull, and equipments; so that it would be impossible to expend another dollar on them to add to their safety or comfort.

One of the advantages of this line is, that these boats have a long night trip, and the eastern or western bound traveller has a good night's rest in a floating palace : if bound eastward, he is not obliged to turn out in the middle of the night to take the cars; if bound westward, the early riser has an opportunity to see some of the most attractive shore scenery, as the boats leave the foot of Long Island Sound, and enter upon the waters of the metropolis. On embarking at either end of the route, a glorious . supper awaits you, if you desire it. A first-class band discourse'; sweet music; and, when tifed with the toils of the dav, you have but to seek your state-room, and, locked in the arms of a marine Morpheus, you sleep till the hour of rising is announced. We have not the space at our command to dilate upon all the beanties and benefits the traveller has by this route.

These boats are now in full trim, and present a splendid sight as they round the Battery daily, decorated with national flags, and other appropriate bunting.

They are commanded by thorough seamen, whose care and attention to the safe navigation of the noble vessels are their first thought, and whose courteous bearing to the patrons of the line has won the respect and regard of thousands of travellers who go to and fro on these the noblest specimens of American naval architecture and beauty afloat. The officers are picked men, those who know their duty, and who conscientiously feel their great responsibility. Perfect system, vigilance, great care, and watchfulness are the guiding precepts in every department of the great line.

As in seasons past, Hall's celebrated brass, reed, and string bands will add their attractions to the pleasures and enjoyments of the trip, on the steamers of this popular line, by their promenade concerts. It is needless to expatiate on the merits of these celebrated bands. The boats leave at five, P.M., from Pier 28 , North River. From Boston the connection is made by trains leaving the Old Colony Railroad depot, South and Kneeland Streets, at 4.30 and $5 \cdot 30$, P.M. 


\section{Nantucketi and Martha's Vineyard.}

INEW ANND DIEFCT ROUTE

BETWEEN

New Yorts, Boston,

AND THESE

\section{GREAT SUMMER RESORTS OF NEW ENGLAND,}

VIA THE

\section{FALL RIVER LINE AND WOODS HOLE.}

Commencing Wednesday, July 7, 1875, and continuing through the season for Summer Travel, passengers may take the Palace Steamships BRISTOL and PROVIDENCE, from Pier 28, North River, New York, at 5 P.M. daily, reaching Fall River on the following morning, there taking a Special Express Train, direct without change of cars, for Woods Hole, making close connection with the fine Steamers RIVER QUEEN and ISLAND HOME, for Nantucket, Martha's Vineyard, Oak Bluffs, Vineyard Highlands, Edgartown, and Katama, reaching Oak Bluffs about 8.30 A.M., and Nantucket about r r.oo A.M.

Returning, passengers may leave Nantucket at I.I5 P.M. (Sundays 2.15 P.M.), and Oak Bluffs at 4.00 P.M. (Sundays 5.00 P.M.), making close connection with the Special Express Train reaching Fall River in season for the Steamer, and arriving at New York about 6.30 A.M.

Passengers by this route avoid delay and change of cars, and make rapid transit from boat to boat, with close connections, all trains being run directly alongside the Steamers at Fall River and Woods Hole.

Travellers from New York will have ample time for breakfast upon the boat at Fall River ; and, upon the return, supper will be served immediately upon the departure of the boat for New York.

Passengers from Boston may take Express Trains from the Old Colony Depot, corner South and Knesland Streets, daily (Sundays excepted), at 8.15, I1.15 A.M., 4.00 P.M., and on Sundays at 5.00 A.M., for Martha's Vineyard, Oak Bluffs, Vineyard Highlands, Edgartown, and Katama (reaching Oak Biuffs about 12 M., 2.45 and 7.30 P.M., Sundays 8.45 A.M.); and for Nantucket at II.I5 A.M., Saturdays excepted, Saturdays at 4 P.M., Sundays at 5.00 A.M., arriving at Nantucket about 5 P.M., Saturdays about 9.30 P.M., Sundays I1.00 A.M.

Returning, Steamers leave Nantucket at 7.30 A.M., and I.I5 P.M., Sundays 2.I5 P.M., reaching Boston at 2.05 P.M., and 7.45 P.M., Sundays 8.45 P.M.; and Oak Bluffs at 6.30, 10.00 A.M., 1.00, 4.00 P.M., Sundays 5.00 P.M., arriving at Boston at 10.30 A.M., 2.05, 6.00, 7.45 P.M., Sundays 8.45 P.M.

Frequent communication between the two islands and the main land is afforded by the regular and excursion boats; and telegraph communication is now being established.

Passengers for Edgartown and Katama reach those points via the new Narrow Gauge Railroad from Oak Bluffs. 
tis $\frac{1}{2}:$

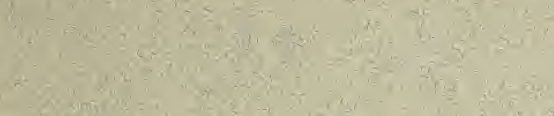

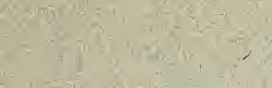

hit $=2.4$

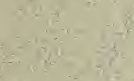

$x$

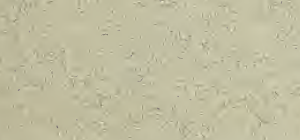

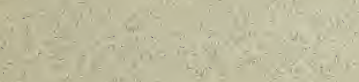

$x^{-1}=x^{2} \rightarrow x^{2}$

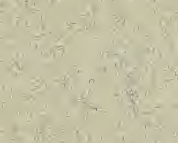

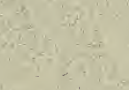

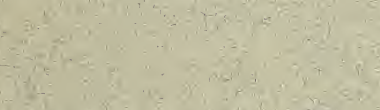

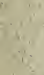

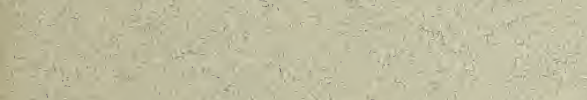

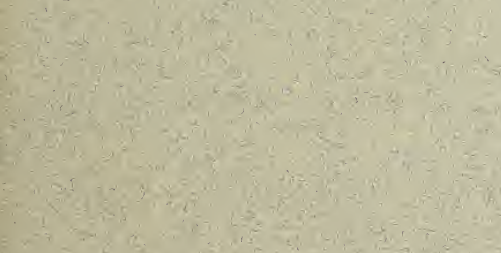

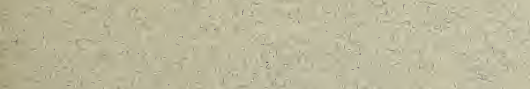

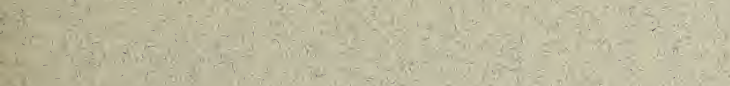

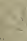

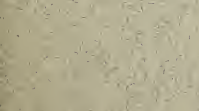

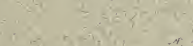

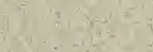

$-\frac{1}{4} 8$ 


\section{FALL RIVER LINE}

(OLD COLONY R. R. \& S. B. CO'S.)

\section{BETWEEN NEW YORK \& BOSTON, VIA \\ Fall River and Newport.}

\section{STEAMERS BRISTOL and PROVIDENCE.}

\section{THE GREAT ROUTE BETWEEN Washington, Baltimore, Philadelphia, and New York,}

Newport and Narragansett Pier, R. I. ; Boston, Taunton, New Bedford, Plymouth, Cape Cod, Nantucket, Martha's Vineyard, Lowell, and Lawrence, Mass ; the White Mountains, Portsmouth, and Concord, N.H. ; Portland and Bangor, Me.; St. John, N.B. ; and Halifax, N.S.

Leave NEW YORK, Pier 28 North River, foot of Murray St, at 5 P.n. Summer, 4 P.M. Winter.

Leave BOSTON, Old Colony Depot, corner South and Kneeland Streets, at 4.30 and 5.30 (Steamboat Express) P.M.

SUNDAY NICHT LINE (Summer only), leave New York at 5 r.M., leave Boston at 6.30 P.M.

Ony 49 Mailes of Rail between New Yosk and Boston. No Night Changes!

Trains equipped with the Westinghouse Air Brake and Miller Platform.

Passengers by this route have a FULL NIGHT'S REST on the Palatial Steamers, reaching New York or Boston at a seasonable hour in the morning, and in time for connections for points beyond. Tickets can be purchased and State Rooms secured in advance in

NEW YORK: Pier 28, N.R. : 401, 529, and 944 Broadway: 23d St. and Broadway: 9 Astor House; 3d Ave. and 125th Street.

BROOKLYN : 10 Court Street; 118 Broadway (Williamsburgh).

BOSTON: 3 Old State House, and at Old Colony Depot.

Tickets sold and Baggage checked through at the following places: PHILADELPHIA, Continental Hotel and Pennsylvania R.R. Depots. BALTIMORE, 143 and 150 Baltimore St. ; Depots of P. W. \& B. \& N. Cent. R.R.'s. WASHINGTON, Peinnsylvania Ave. and isth St.; Pennsylvania Ave. and 6th St.; 485 Pennsylvania Ave: ; Depots of B. \& P. R.R and B. \& O. R.R. RICHMOND, 826 and 1201 Main St. : Pallard Hotise, and R. F. \& P. R.R. Depot. LYNCHBURG, W. C. V. M. \& Gt. So. R.R Depot. NEWARK, I84 Market St. Tickets also for sále at all principal Ticket Offices.

BORDEN \& LOVELL, Agents O.C.S. B. Co. - . - - NEW YORK. GEO. L. CONNOR, Gen. Passenger Agent 0. C. S. B. Co. - NEW YORK. J. SPRAGUE, Jr., Gen. Passenger Agent O. C. R.R. Co. - - BOSTON. J. R. KENDRICK, superintendent O. C. R.R. Co. - - - - BOSTON. 